\title{
PENINGKATAN KEMAMPUAN BERPIKIR KRITIS MATEMATIS DAN KEMANDIRIAN BELAJAR SISWA SMP MELALUI PEMBELAJARAN BERBASIS MASALAH
}

\author{
Tanti Jumaisyaroh, E.E. Napitupulu dan Hasratuddin \\ Program Pasca Sarjana Universitas Negeri Medan \\ Email : tanti.jss@gmail.com
}

\begin{abstract}
ABSTRAK
Tujuan penelitian kuasi eksperimen ini untuk mengetahui: (1) perbedaan peningkatan kemampuan berpikir kritis matematis siswa yang diberi pembelajaran berbasis masalah dengan siswa yang diberi pembelajaran langsung; (2) interaksi pembelajaran dengan kemampuan awal matematika terhadap peningkatan kemampuan berpikir kritis matematis siswa; (3) perbedaan peningkatan kemandirian belajar siswa yang diberi pembelajaran berbasis masalah dengan siswa yang diberi pembelajaran langsung; (4) interaksi pembelajaran dengan kemampuan awal matematika terhadap peningkatan kemandirian belajar siswa. Populasinya adalah seluruh siswa SMP Swasta Ar-rahman Percut dan sampelnya adalah siswa kelas VIII sebanyak 60 orang. Instrumen yang digunakan terdiri dari tes kemampuan berpikir kritis matematis dan skala kemandirian belajar. Data dianalisis dengan uji ANAVA dua jalur. Dari hasil analisis diperoleh: (1) peningkatan kemampuan berpikir kritis matematis siswa yang diberi pembelajaran berbasis masalah lebih tinggi daripada yang diberi pembelajaran langsung; (2) tidak terdapat interaksi antara pembelajaran dengan kemampuan awal matematika terhadap peningkatan kemampuan berpikir kritis matematis; (3) peningkatan kemandirian belajar siswa yang diberi pembelajaran berbasis masalah lebih tinggi daripada yang diberi pembelajaran langsung (4) tidak terdapat interaksi antara pembelajaran dengan kemampuan awal matematika terhadap peningkatan kemandirian belajar.
\end{abstract}

Kata Kunci: Berpikir Kritis Matematis, Kemandirian Belajar

\begin{abstract}
The purposes of this research were to know: (1) The difference of improvement in mathematical critical thinking ability of students that given problem-based learning with students that given direct learning; (2) The interaction between the model of learning with students' mathematical previous knowledge toward the improvement in mathematical critical thinking ability; (3) The difference of improvement in self-regulated learning of students that given problem-based learning with students that given direct learning; (4) The interaction between the model of learning with students' mathematical previous knowledge toward the improvement in self-regulated learning. The population of this research is all students of SMP Swasta Ar-rahman Percut and the sample of this research is grade eight with taken sample two classes (experiment and control) with sample 60 students. The instrument of this research were: test of mathematical critical thinking and scale of self-regulated learning. Based of the results analysis, it showed that: (1) Improvement of the students' ability in mathematical critical thinking that given problem-based learning was higher than the students' ability that given direct learning; (2) There did not exist interaction between model of learning and students' mathematical previous knowledge toward the improvement ability mathematical critical thinking; (3) Improvment of the students' self-regulated learning that given problem-based learning was higher than the students' ability that given direct learning; (4) There did not exist interaction between model of learning and students' mathematical previous knowledge toward the improvement self-regulated learning.
\end{abstract}

Keywords: Critical Thinking Mathematics, Self-Regulated Learning. 


\section{Pendahuluan}

Matematika merupakan salah satu bidang studi yang menduduki peranan penting dalam pendidikan. Hal ini dapat dilihat dari waktu jam pelajaran sekolah lebih banyak dibandingkan pelajaran lain. Selain itu, sebagaimana yang tercantum dalam standar isi untuk satuan pendidikan dasar dan menengah mata pelajaran matematika (Depdiknas, 2006 : 139) telah disebutkan bahwa mata pelajaran matematika perlu diberikan kepada semua peserta didik mulai dari sekolah dasar untuk membekali peserta didik dengan kemampuan berpikir logis, analitis, sistematis, kritis, dan kreatif, serta kemampuan bekerjasama. Harapannya dengan pembelajaran matematika siswa dapat memiliki kemampuan berpikir tersebut terutama yang mengarah kepada kemampuan berpikir kritis matematis.

Berpikir kritis matematis merupakan dasar proses berpikir untuk menganalisis argumen dan memunculkan gagasan terhadap tiap makna untuk mengembangkan pola pikir secara logis. Hal tersebut juga diungkapkan oleh Noer (2009:474) bahwa berpikir kritis matematis merupakan sebuah proses yang mengarah pada penarikan kesimpulan tentang apa yang harus kita percayai dan tindakan yang akan dilakukan. Menurut Susanto (2013:121) berpikir kritis matematis adalah suatu kegiatan berpikir tentang idea atau gagasan yang berhubungan dengan konsep atau masalah yang diberikan.

Sedangkan menurut Ennis (dalam Ismaimuza, 2010:2) berpikir kritis matematis adalah suatu proses berpikir dengan tujuan mengambil keputusan yang masuk akal tentang apa yang diyakini berupa kebenaran dapat dilakukan dengan benar. Dari beberapa pendapat ahli di atas maka dapat disimpulkan bahwa kemampuan berpikir kritis matematis adalah suatu kecakapan berpikir secara efektif yang dapat membantu seseorang untuk membuat, mengevaluasi, serta mengambil keputusan tentang apa yang diyakini atau dilakukan. Adapun indikator kemampuan berpikir kritis matematis yang digunakan dalam penelitian ini mencakup: kemampuan mengidentifikasi, kemampuan menggeneralisasi, kemampuan menganalisis algoritma dan kemampuan memecahkan masalah.

Keterampilan berpikir kritis matematis sangat penting bagi siswa karena dengan keterampilan ini siswa mampu bersikap rasional dan memilih alternatif pilihan yang terbaik bagi dirinya. Selain itu, menanamkan kebiasaan berpikir kritis matematis bagi pelajar perlu dilakukan agar mereka dapat mencermati berbagai persoalan yang terjadi dalam kehidupan sehari-hari (Somakim, 2011:43). 
Namun kenyataannya, berdasarkan hasil penelitian Syahbana (2012) menunjukkan bahwa masih rendahnya rata-rata kemampuan berpikir kritis matematis siswa SMP. Nilai rata-rata kemampuan berpikir kritis matematis siswa SMP hanya 68 kalau dalam skala 0100, nilai ini baru termasuk dalam kategori cukup. Selain itu, dari penelitian awal dengan memberikan tes kemampuan berpikir kritis matematis yang dilakukan oleh peneliti di SMP Ar-rahman Percut, dari 30 siswa hanya 2 orang yang dapat menjawab soal dengan benar dan lengkap, sedangkan yang lainnya hanya menebaknebak jawaban saja. Berdasarkan hal tersebut maka dapat disimpulkan bahwa kemampuan berpikir kritis matematis siswa SMP Ar-Rahman Percut masih rendah.

Selain kemampuan berpikir kritis matematis, fokus penelitian lainnya merupakan salah satu aspek afektif yaitu kemandirian belajar. Kemandirian belajar adalah suatu keterampilan belajar yang dalam proses belajar individu didorong, dikendalikan, dan dinilai oleh diri individu itu sendiri (Lilik dkk, 2013: 64). Sehingga dengan demikian, peserta didik mengatur pembelajarannya sendiri dengan mengaktifkan kognitif, afektif dan perilakunya yang ada pada dirinya sehingga tercapai tujuan belajar yang diinginkan. Ada beberapa indikator yang dapat digunakan untuk mengukur kemandirian belajar yaitu: 1) inisiatif belajar, 2) mendiagnosa kebutuhan belajar, 3) menetapkan target dan tujuan belajar, 4) memonitor, mengatur dan mengontrol kemajuan belajar, 5) memandang kesulitan sebagai tantangan, 6) memanfaatkan dan mencari sumber yang relevan, 7) memilih dan menerapkan strategi belajar, 8) mengevaluasi proses dan hasil belajar dan 9) memiliki self concept atau konsep diri (Sumarmo, 2004:5).

Perlunya pengembangan kemandirian belajar pada individu yang belajar matematika juga didukung oleh beberapa hasil studi temuan antara lain adalah individu yang memiliki kemandirian belajar yang tinggi cenderung belajar lebih baik, mampu memantau, mengevaluasi, dan mengatur belajarnya secara efektif; menghemat waktu dalam menyelesaikan tugasnya, mengatur belajar dan waktu secara efisien, dan memperoleh skor yang lebih tinggi dalam pelajaran sains (Hargis dalam Sumarmo, 2004:5). Namun, saat ini kenyataannya bahwa kemandirian belajar belum tersosialisasi dan berkembang di kalangan peserta didik, mereka menganggap bahwa guru satu-satunya sumber ilmu sehingga menyebabkan siswa memiliki ketergantungan dengan orang lain terutama kepada guru. 
Padahal ilmu pengetahuan akan bisa didapatkan melalui sumber-sumber, tempat, sarana dan lingkungan sekitarnya seperti melalui perpustakaan, laboratorium dan internet (Yamin , 2008: 204-205). Keadaan tersebut juga dialami oleh siswa di SMP Ar-Rahman Percut dimana siswa cenderung pasif dan hanya menerima informasi dan perintah dari guru saja, siswa jarang mengajukan pertanyaan mengenai materi yang disampaikan serta siswa sering mengalami keraguan dalam memecahkan permasalahan, karena siswa tidak percaya akan kemampuan mereka sendiri sehingga menyebabkan kemandirian belajar yang dimiliki oleh siswa masih rendah.

Kemampuan berpikir kritis matematis dan kemandirian belajar siswa yang masih rendah disebabkan oleh beberapa faktor salah satunya pembelajaran yang dilakukan oleh guru yang mana guru masih kurang tepat memilih dan menggunakan model pembelajaran yang dapat meningkatkan kemampuan berpikir kritis matematis dan kemandirian belajar siswa. Kemampuan berpikir kritis matematis dan kemandirian belajar siswa yang masih rendah disebabkan oleh beberapa faktor salah satunya pembelajaran yang dilakukan oleh guru yang mana selama ini guru masih kurang tepat memilih dan menggunakan model pembelajaran yang sesuai dalam menyampaikan materi dan tujuan pembelajaran. Dalam pembelajaran matematika, guru kebanyakan menerapkan pembelajaran langsung. Berdasarkan hasil survey penelitian Santoso (2013) di beberapa sekolah ditemukan bahwa masih banyak guru matematika di segala tingkat sekolah, baik SD, SMP maupun SMA yang masih menggunakan pembelajaran langsung atau pembelajaran yang berpusat pada guru (teacher centered learning).

Pembelajaran langsung merupakan pembelajaran dimana guru bertindak sebagai pemimpin sekaligus fasilitator belajar, sedangkan siswa berperan sebagai individu yang belajar sehingga proses pembelajaran cenderung didominasi oleh guru atau terpusat oleh guru (Cahyo, 2013:239). Jadi, pada pembelajaran langsung siswa diberikan informasi secara langsung oleh guru terkait dengan materi yang dipelajarinya dan siswa tidak diberikan kebebasan untuk mengkonstruksikan sendiri pengetahuannya sehingga siswa kurang terlibat pada proses pembelajaran. Hal ini yang menyebabkan kemampuan berpikir kritis matematis dan kemandirian belajar siswa masih rendah.

Berdasarkan hal di atas, maka guru perlu memilih suatu model pembelajaran yang tepat untuk meningkatkan kemampuan berpikir kritis 
matematis maupun kemandirian belajar siswa dimana salah satunya yaitu dengan menerapkan pembelajaran berbasis masalah. Pembelajaran berbasis masalah merupakan pembelajaran yang mengacu pada langkah-langkah pembelajaran berikut: (1) orientasi siswa pada masalah, (2) mengorganisir siswa untuk belajar (3) membimbing penyelidikan individual maupun kelompok, (4) mengembangkan dan menyajikan hasil karya dan, (5) menganalisis dan mengevaluasi proses pemecahan masalah (Arends, 2007:57). Pembelajaran berbasis masalah memiliki karakteristik yaitu pembelajaran yang dipusatkan pada siswa melalui pemberian masalah di awal pembelajaran sebagai titik awal akuisisi dan integrasi pengetahuan baru (Cahyo, 2013: 283). Melalui pemberian masalah pada awal pembelajaran maka akan mendorong siswa untuk dapat menyelesaikan permasalahan yang diberikan melalui kegiatan menganalisis, mengkritik, dan menarik kesimpulan dari permasalahan tersebut sehingga dapat melatih kemampuan berpikir kritis matematis siswa. Berdasarkan hal tersebut, diharapkan nantinya dengan diterapkannya pembelajaran berbasis masalah di kelas maka dapat meningkatkan kemampuan berpikir kritis siswa.
Pembelajaran berbasis masalah juga dipilih karena pembelajaran berbasis masalah memiliki sifat berpusat pada siswa dan menekankan pada kemandirian belajar (Riyanto, 2010: 291). Pada penerapan pembelajaran berbasis masalah selalu dimulai dengan guru mengajukan masalah kepada siswa untuk mendorong siswa belajar kemudian siswa akan merumuskan kebutuhan belajarnya baik secara individu maupun secara berkelompok. Hal ini ditindaklanjuti dengan mengakses sumber belajar dan disini terjadi proses asimilasi struktur kognitif sehingga melalui rangkaian kegiatan tersebut diharapkan karakter kemandirian belajar anak akan tumbuh (Napitupulu, 2008:39). Dengan demikian, diharapkan dengan penerapan pembelajaran berbasis masalah dapat meningkatkan kemandirian belajar siswa.

Hal yang perlu diperhatikan oleh guru selain kemampuan berpikir kritis matematis dan kemandirian belajar siswa adalah kemampuan awal matematika siswa. Kemampuan awal matematika merupakan kecakapan yang dimiliki oleh siswa sebelum proses pembelajaran matematika dilaksanakan (Ismaimuza, 2010:3). Kemampuan awal yang dimiliki oleh siswa juga bervariasi antara siswa yang satu dengan yang lainnya jika ditinjau dari tingkat penguasaan siswa maka dapat dibedakan antara siswa yang 
memiliki kemampuan awal tinggi, sedang dan rendah. Kemampuan awal matematika siswa berkontribusi besar dalam prestasi belajar matematika siswa.

Kemampuan awal matematika siswa perlu diperhatikan guru sebelum melakukan pembelajaran disebabkan adanya hirarki dalam belajar matematika artinya pemahaman materi yang baru mensyaratkan penguasaan materi sebelumnya (Usdiyana, dkk, 2009:8). Namun, kenyataan selama ini guru jarang memperhatikan kemampuan awal yang dimiliki oleh siswa. Seperti yang diungkapkan oleh Sutama (2011:15) bahwa pembelajaran matematika selama ini tidak efektif salah satu faktor penyebabnya adalah guru dalam mengajar cenderung kurang memperhatikan kemampuan awal siswa. Jadi, seorang guru harus mengetahui kemampuan awal matematika siswa untuk memperkecil peluang kesulitan yang dihadapi siswa dalam memahami materi yang akan diajarkan. Selain itu, dengan mengetahui kemampuan awal siswa yang bervariasi guru dapat memilih model pembelajaran yang cocok untuk digunakan di kelas sehingga pembelajaran yang berlangsung di kelas dapat efektif. Berdasarkan hal tersebut, maka pada penelitian ini diduga akan terdapat interaksi kemampuan awal matematika dan pembelajaran terhadap peningkatan kemampuan berpikir kritis matematis dan kemandirian belajar siswa. Oleh sebab itu, penulis tertarik melakukan penelitian yang berjudul peningkatan kemampuan berpikir kritis matematis dan kemandirian belajar siswa SMP Ar-Rahman Percut melalui pembelajaran berbasis masalah.

Berdasarkan latar belakang masalah yang diuraikan di atas, maka permasalahan yang menjadi bahan pengkajian dalam penelitian ini adalah sebagai berikut :

1. Apakah peningkatan kemampuan berpikir kritis matematis siswa yang diberi pembelajaran berbasis masalah lebih tinggi daripada siswa yang diberi pembelajaran langsung?

2. Apakah terdapat interaksi antara pembelajaran dengan kemampuan awal matematika siswa terhadap peningkatan kemampuan berpikir kritis matematis siswa?

3. Apakah peningkatan kemandirian belajar siswa yang diberi pembelajaran berbasis masalah lebih baik daripada siswa yang diberi pembelajaran langsung?

4. Apakah terdapat interaksi antara pembelajaran dengan kemampuan awal matematika siswa terhadap peningkatan kemandirian belajar siswa?

Adapun tujuan penelitian ini adalah sebagai berikut: 
1. Untuk mengetahui perbedaan peningkatan kemampuan berpikir kritis matematis siswa yang diberi pembelajaran berbasis masalah dengan siswa yang diberi pembelajaran langsung.

2. Untuk mengetahui interaksi antara pembelajaran dengan kemampuan awal matematika siswa terhadap peningkatan kemampuan berpikir kritis matematis siswa.

3. Untuk mengetahui perbedaan peningkatan kemandirian belajar siswa yang diberi pembelajaran berbasis masalah dengan siswa yang diberi pembelajaran langsung.

4. Untuk mengetahui interaksi antara pembelajaran dengan kemampuan awal matematika siswa terhadap peningkatan kemandirian belajar siswa.

\section{Metode}

Jenis penelitian yang digunakan dalam penelitian ini adalah kuasi eksperimen yang bertujuan untuk mengetahui peningkatan kemampuan berpikir kritis matematis dan kemandirian belajar siswa melalui pembelajaran berbasis masalah. Penelitian ini dilaksanakan di SMP Ar-Rahman Percut yang berlokasi di Jalan Kangkungan Dusun II Desa Percut Kecamatan Percut Sei Tuan pada semester genap tahun ajaran 2013/2014 yang direncanakan berlangsung pada awal sampai akhir Maret 2014 selama 5 kali pertemuan untuk kelas eksperimen dan kelas kontrol. Populasi penelitian ini adalah seluruh siswa di sekolah SMP ArRahman Percut sedangkan sampel penelitian ini adalah siswa kelas VIII SMP Ar-Rahman Percut dengan mengambil sampel dua kelas sebanyak 60 orang dimana terdiri dari 30 orang siswa pada kelas VIII-A sebagai kelas eksperimen dan 30 orang siswa pada kelas VIII-B sebagai kelas kontrol.

Variabel bebas dalam penelitian ini adalah pembelajaran berbasis masalah dan pembelajaran langsung, sedangkan variabel terikatnya adalah kemampuan berpikir kritis matematis dan kemandirian belajar siswa serta variabel kontrol yaitu kemampuan awal matematika siswa dalam kelompok (tinggi, sedang dan rendah).

Desain penelitian yang digunakan dalam penelitian ini adalah desain kelompok pre test-post test control group design. Instrumen yang digunakan untuk memperoleh data dalam penelitian ini adalah tes kemampuan awal matematika, tes kemampuan berpikir kritis matematis, dan skala kemandirian belajar yang mana nantinya akan dinilai oleh validator yang berkompeten yang meliputi dosen dan guru matematika di sekolah dan diujicobakan terhadap responder di luar kelas sampel. Data dalam penelitian ini 
terdiri dari pengujian normalitas, pengujian homogenitas, pengujian perbedaan rata-rata, perhitungan indeks gain, dan pengujian hipotesis. Pengujian seluruh hipotesis statistik dalam penelitian ini menggunakan rumus ANAVA Dua Jalur.

Hasil dan Pembahasan
Setelah pengujian prasyarat analisis data di dapat bahwa N-Gain berpikir kritis matematis dan N-Gain kemandirian belajar berdistribusi normal dan homogen maka analisis yang digunakan adalah analisis parametrik dengan menggunakan anava dua jalur. Hasil rangkuman anava dua jalur untuk pengujian hipotesis pertama dan kedua tersajikan pada tabel 4.1 berikut:

Tabel 1 Rangkuman Uji ANAVA Dua Jalur Gain Berpikir Kritis Matematis

\begin{tabular}{|c|c|c|c|c|c|}
\hline Source & $\begin{array}{l}\text { Type III Sum of } \\
\text { Squares }\end{array}$ & Df & $\begin{array}{l}\text { Mean } \\
\text { Square }\end{array}$ & $\mathbf{F}$ & Sig. \\
\hline Corrected Model & $1.290(\mathrm{a})$ & 5 & .258 & 33.521 & .000 \\
\hline Intercept & 10.608 & 1 & 10.608 & 1378.013 & .000 \\
\hline Pembelajaran & .885 & 1 & .885 & 114.940 & .000 \\
\hline KAM & 238 & 2 & .119 & 15.466 & .000 \\
\hline Pembelajaran * KAM & .005 & 2 & .003 & .327 & .722 \\
\hline Error & .416 & 54 & .008 & & \\
\hline Total & 13.702 & 60 & & & \\
\hline Corrected Total & 1.706 & 59 & & & \\
\hline
\end{tabular}

Berdasarkan tabel di atas maka pengujian hipotesis statistik pertama dilakukan untuk menguji apakah peningkatan kemampuan berpikir kritis matematis siswa yang diajar dengan pembelajaran berbasis masalah lebih tinggi daripada siswa yang diajar dengan pembelajaran langsung. Hasil yang diperoleh menunjukkan bahwa dengan nilai $F$ pada faktor pembelajaran (pembelajaran berbasis masalah dan pembelajaran langsung) sebesar 114,94 dengan nilai signifikansi 0,000 lebih kecil dari taraf signifikansi 0,05 , sehingga $\mathrm{H}_{\mathrm{o}}$ ditolak. Dengan kata lain, terdapat perbedaan peningkatan kemampuan berpikir kritis matematis antara siswa yang diberi pembelajaran berbasis masalah dibandingkan dengan siswa yang diberi pembelajaran langsung.

Pengujian hipotesis statistik kedua dilakukan untuk menguji apakah terdapat interaksi antara kemampuan awal matematika siswa dan pembelajaran terhadap peningkatan kemampuan berpikir kritis matematis siswa. Hasil yang diperoleh menunjukkan bahwa pada taraf signifikan sebesar 5\% atau $\alpha=0,05$ nilai F sebesar 0,327 dengan nilai signifikansi sebesar 0,722 lebih besar dari taraf 
signifikansi yaitu 0,05 , sehingga $\mathrm{H}_{0}$ diterima. Oleh karena itu, dapat disimpulkan bahwa tidak terdapat interaksi antara pembelajaran (pembelajaran berbasis masalah dan pembelajaran langsung) dan KAM siswa (tinggi, sedang dan rendah) terhadap peningkatan kemampuan berpikir kritis matematis siswa. Secara grafik, dapat dilihat pada gambar 1 berikut ini.

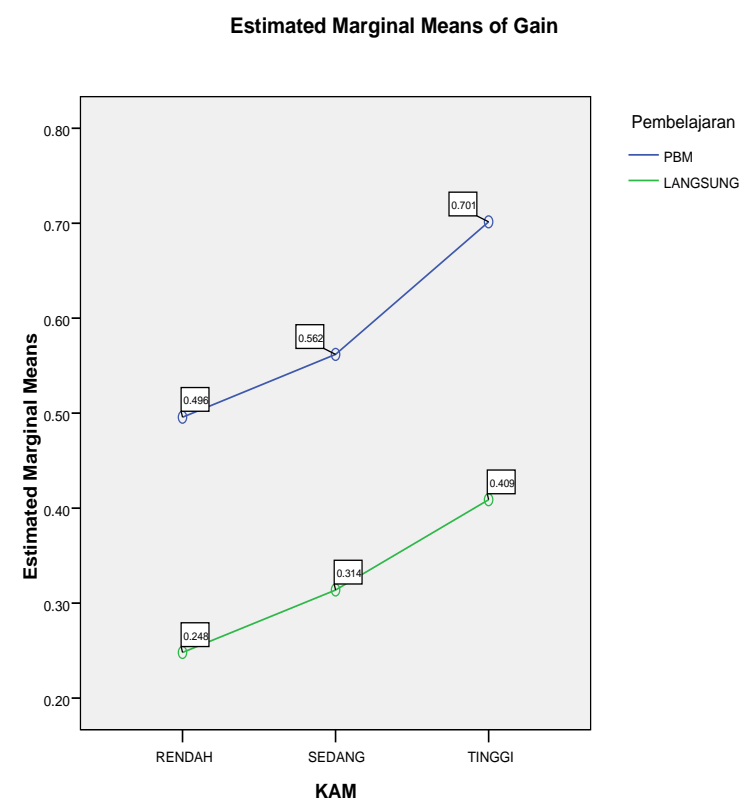

Gambar 1. Interaksi Antara Pembelajaran dan KAM Siswa Terhadap Peningkatan Kemampuan Berpikir Kritis Matematis Siswa

Dari Gambar 1 di atas memperlihatkan bahwa garis kelas eksperimen memperlihatkan kesejajaran atau tidak berpotongan dengan garis kelas kontrol. Dari gambar $1 \mathrm{di}$ atas terlihat juga bahwa rata-rata peningkatan kemampuan berpikir kritis matematis siswa yang diberi pembelajaran berbasis masalah yaitu untuk kategori KAM rendah $(0,496)$, kategori KAM sedang $(0,562)$ dan kategori KAM tinggi $(0,701)$ sedangkan rata-rata peningkatan kemampuan berpikir kritis matematis siswa yang diberi pembelajaran langsung yaitu: kategori KAM rendah $(0,248)$, kategori KAM sedang (0,314) dan kategori KAM tinggi $(0,409)$. Selanjutnya, selisih rata-rata kemampuan berpikir kritis matematis antara siswa yang diberi pembelajaran berbasis masalah dan siswa yang diberi pembelajaran langsung berturut-turut untuk siswa kategori KAM rendah sebesar 0,248, kategori KAM sedang sebesar 0,248 dan kategori KAM tinggi sebesar 0,292. Selisih rata-rata peningkatan untuk semua kategori KAM tersebut jika diuji secara statistik perbedaannya tidak begitu berarti sehingga dapat disimpulkan tidak terdapat interaksi antara pembelajaran dengan KAM terhadap peningkatan kemampuan berpikir kritis matematis siswa.

Selanjutnya, hipotesis yang akan diuji adalah hipotesis ketiga dan keempat dimana hasil rangkuman anava dua jalur untuk pengujian hipotesis ketiga dan keempat tersajikan pada tabel 4.2 berikut ini. 
Tabel 2. Rangkuman Uji ANAVA Dua Jalur Gain Kemandirian Belajar

\begin{tabular}{|c|c|c|c|c|c|}
\hline Source & $\begin{array}{l}\text { Type III Sum of } \\
\text { Squares }\end{array}$ & Df & Mean Square & $\mathrm{F}$ & Sig. \\
\hline Corrected Model & $2.276(\mathrm{a})$ & 5 & .455 & 244.046 & .000 \\
\hline Intercept & 7.258 & 1 & 7.258 & 3890.657 & .000 \\
\hline Pembelajaran & 1.889 & 1 & 1.889 & 1012.456 & .000 \\
\hline KAM & .037 & 2 & .019 & 9.927 & .000 \\
\hline Pembelajaran * KAM & 4.16E-006 & 2 & $2.08 \mathrm{E}-006$ & .001 & .999 \\
\hline Error & .101 & 54 & .002 & & \\
\hline Total & 10.755 & 60 & & & \\
\hline Corrected Total & 2.377 & 59 & & & \\
\hline
\end{tabular}

Berdasarkan tabel maka pengujian hipotesis statistik ketiga dilakukan untuk menguji apakah peningkatan kemandirian belajar siswa yang diajar dengan pembelajaran berbasis masalah lebih baik daripada siswa yang diajar dengan pembelajaran langsung. Hasil yang diperoleh menunjukkan bahwa pada taraf signifikan sebesar $5 \%$ atau $\quad \alpha=0,05$ nilai $F$ untuk faktor pembelajaran (pembelajaran berbasis masalah dan pembelajaran langsung) sebesar 1012,456 dengan signifikansi 0,000 lebih kecil dari taraf signifikansi 0,05 sehingga hipotesis nol ditolak. Dengan kata lain, terdapat perbedaan peningkatan kemandirian belajar antara siswa yang diberi pembelajaran berbasis masalah dibandingkan dengan siswa yang diberi pembelajaran langsung.

Pengujian hipotesis statistik keempat dilakukan untuk menguji apakah terdapat interaksi antara kemampuan awal matematika siswa dan pembelajaran terhadap peningkatan kemandirian belajar siswa. Hasil yang diperoleh menunjukkan bahwa terlihat bahwa nilai $\mathrm{F}$ untuk faktor pembelajaran (pembelajaran berbasis masalah dan pembelajaran langsung) sebesar 0,001 dan dengan nilai signifikansi sebesar 0,999. Karena nilai signifikansi lebih besar dari nilai taraf signifikan 0,05, maka Ho diterima, yang berarti tidak terdapat interaksi antara pembelajaran dengan kemampuan awal matematika siswa terhadap peningkatan kemandirian belajar siswa. Secara grafik, dapat dilihat pada gambar 2 berikut ini.

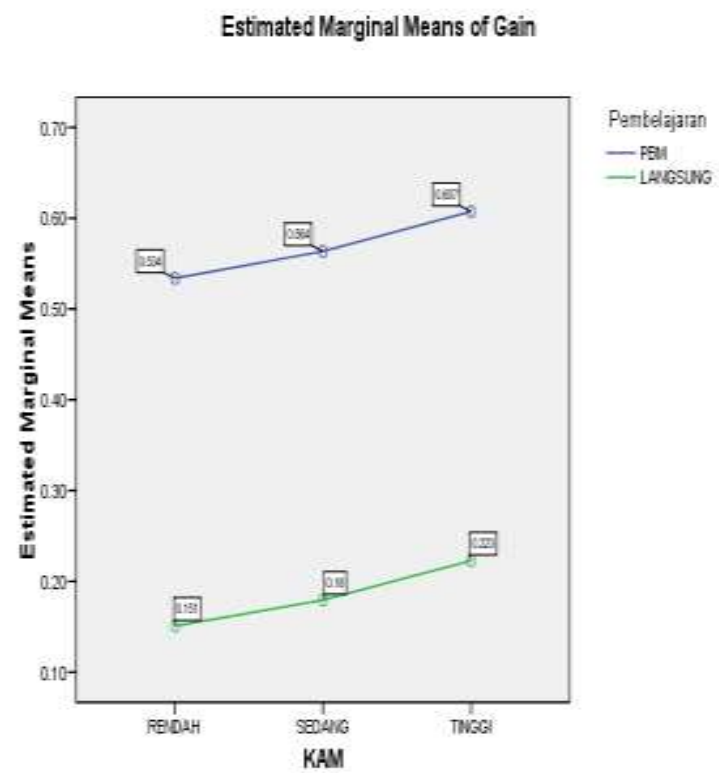

Gambar 2 Interaksi Antara Pembelajaran dan KAM Siswa Terhadap Peningkatan Kemandirian Belajar Siswa 
Dari Gambar 2 di atas memperlihatkan bahwa garis kelas eksperimen memperlihatkan kesejajaran atau tidak berpotongan dengan garis kelas kontrol. Dari gambar 2 di atas terlihat juga bahwa rata-rata peningkatan kemandirian belajar siswa yang menggunakan pembelajaran berbasis masalah yaitu untuk kategori KAM rendah (0,534), kategori KAM sedang $(0,564)$ dan kategori KAM tinggi $(0,607)$ sedangkan rata-rata peningkatan kemandirian belajar siswa yang diberi pembelajaran langsung yaitu: kategori KAM rendah $(0,151)$, kategori KAM sedang $(0,18)$ dan kategori KAM tinggi $(0,223)$. Selanjutnya, selisih rata-rata kemandirian belajar antara siswa yang diberi pembelajaran berbasis masalah dan siswa yang diberi pembelajaran langsung berturut-turut untuk siswa kategori KAM rendah sebesar 0,383, kategori KAM sedang sebesar 0,384 dan kategori KAM tinggi sebesar 0,384. Selisih rata-rata peningkatan untuk semua kategori KAM tersebut jika diuji secara statistik perbedaannya tidak begitu berarti sehingga dapat disimpulkan tidak terdapat interaksi antara pembelajaran dengan KAM terhadap peningkatan kemandirian belajar siswa.

Berikut ini akan diuraikan beberapa faktor yang terkait dalam penelitian ini, yaitu faktor pembelajaran, kemampuan berpikir kritis matematis, kemandirian belajar, interaksi antara pembelajaran yang digunakan dean kemampuan awal matematika siswa terhadap peningkatan kemampuan berpikir kritis matematis dan kemandirian belajar siswa.

\section{Faktor Pembelajaran}

Salah satu faktor yang paling berpengaruh terhadap kemampuan berpikir kritis matematis dan kemandirian belajar siswa adalah pembelajaran khususnya pembelajaran berbasis masalah. Pembelajaran berbasis masalah dilaksanakan atas lima tahap. Pada tahap 1 yaitu orientasi siswa pada masalah siswa dimana siswa diberikan LAS yang berisi permasalahan yang telah dirancang untuk diselesaikan. Pada tahap ini, siswa dilatih untuk berpikir dan bekerja secara mandiri terlebih dahulu dalam menyelesaikan permasalahan yang diberikan oleh guru. Hal tersebut berbanding terbalik dengan pembelajaran langsung dimana guru memberikan permasalahan setelah materi diajarkan oleh guru. Selain itu, siswa tidak diberikan LAS. Siswa hanya diberikan soal rutin yang terdapat di buku pelajaran.

Selanjutnya pada tahap kedua yaitu pengorganisasian siswa dalam kelompok belajar dimana guru membagi siswa ke dalam beberapa kelompok heterogen baik dari segi kemampuan awal (berdasarkan nilai KAM), jenis kelamin maupun suku 
yang mana setiap kelompok terdiri atas 5 orang. Siswa tampak berusaha dengan maksimal menggunakan kemampuan berpikir yang dimilikinya untuk menemukan konsep dari masalah. Sedangkan pada pembelajaran langsung guru hampir tidak pernah membuat sistem kelompok dalam pembelajaran. Guru hanya menyampaikan materi pembelajaran kepada siswa.

Pada tahap ketiga yaitu membimbing penyelidikan kelompok. Guru mendorong siswa untuk berpartisipasi dan berinteraksi dengan temannya dalam diskusi kelompok. Guru mengalami kendala manakala terdapat beberapa kelompok mengalami kesulitan dalam menyelesaiakn masalah yang terdapat pada LAS. Adapun upaya yang dilakukan oleh guru adalah memberdayakan siswa dalam bekerjasama dalam kelompok secara maksimal dengan memanfaatkan buku referensi yang ada. Guru hanya memberikan bantuan atau scaffolding secara tidak langsung berupa petunjuk, pertanyaan atau informasi yang dapat membantu siswa yang berkaitan dengan materi pembelajaran. Sedangkan pada pembelajaran langsung, guru memberikan bantuan secara langsung kepada siswa yang mengalami kesulitan.

Pada tahap ke empat yaitu mengembangkan dan menyajikan hasil karya dimana guru meminta salah satu kelompok untuk mempersentasikan hasil diskusi mereka di depan kelas. Pada tahap kelima yaitu menganalisis dan mengevaluasi proses pemecahan masalah dimana kelompok lain bisa memberikan tanggapan kepada kelompok yang persentasi. Pada tahap kemampuan berpikir kritis siswa terbentuk dimana siswa membandingkan hasil pekerjaan kelompoknya dengan hasil kerja kelompok lain dan siswa dapat mengajukan pertanyaan kepada kelompok penyaji. Jadi, siswa tidak menerima informasi dari orang lain begitu saja. Sedangkan pada pembelajaran langsung guru memberikan soal dan selanjutnya beberapa siswa disuruh mengerjakan soal latihan di papan tulis lalu guru mengecek hasil jawaban siswa tersebut. Berdasarkan uraian di atas dari kedua pembelajaran ini terdapat perbedaan pada proses pembentukan pengetahuan yang dilakukan guru. Perbedaan inilah yang dianggap mendukung hasil penelitian yang menunjukkan bahwa pembelajaran berbasis masalah efektif untuk meningkatkan kemampuan berpikir kritis matematis dan kemandirian belajar siswa daripada pembelajaran langsung.

\section{Kemampuan Berpikir Kritis Matematis}

Dalam rangka meningkatkan kemampuan berpikir kritis matematis siswa pada kelas eksperimen diberikan 
pembelajaran berbasis masalah. Pada pembelajaran berbasis masalah dimana tahap pembelajaran yang memberikan kontribusi yang besar dalam meningkatkan kemampuan berpikir kritis siswa adalah tahap orientasi siswa pada masalah yaitu dengan memberikan permasalahan yang terdapat pada LAS dimana siswa dapat mengidentifikasi informasi yang relevan pada permasalahan, selanjutnya siswa berpikir menemukan solusi yang digunakan dalam menyelesaikan permasalahan tersebut. Kondisi ini memicu siswa untuk menggunakan kemampuan dasar yang dimilikinya untuk mendapatkan solusi terhadap permasalahan dan juga menemukan konsep yang baru. Pada aktivitas ini, siswa mendapatkan kesempatan untuk memberdayakan kemampuan berpikirnya.

Selain itu, pada tahap mengembangkan dan menyajikan hasil karya, kemampuan berpikir kritis matematis siswa juga dibentuk dimana siswa dapat mengkritik, bertanya, memberikan saran dan memberikan penilaian terhadap hasil pekerjaan kelompok penyaji. Jadi, melalui tahap pembelajaran berbasis masalah tersebut memberikan pengaruh yang signifikan terhadap peningkatan kemampuan berpikir kritis matematis siswa.
Dari hasil penelitian diperoleh bahwa seluruh indikator kemampuan berpikir kritis matematis mengalami peningkatan baik di kelas eksperimen maupun di kelas kontrol dimana peningkatan kemampuan berpikir kritis matematis siswa yang diberi pembelajaran berbasis masalah lebih tinggi daripada siswa yang diberi pembelajaran langsung.Walaupun, peningkatan kemampuan berpikir kritis matematis siswa pada kedua kelas ini jika dikategorikan masih berada dalam kategori sedang dimana diperoleh bahwa $\mathrm{N}$-gain kemampuan berpikir kritis matematis siswa di kelas eksperimen yang diberi pembelajaran berbasis masalah sebesar 0,579 dan pada siswa di kelas kontrol sebesar 0,3153. Peningkatan kemampuan berpikir kritis yang diperoleh dalam penelitian ini lebih baik jika dibandingkan dengan hasil penelitian Fachrurazi (2011) yang mana peningkatan kemampuan berpikir kritis matematis siswa di kelas eksperimen yang diberi pembelajaran berbasis masalah sebesar 0,414 dan peningkatan kemampuan berpikir kritis matematis siswa di kelas kontrol sebesar 0,215.

\section{Kemandirian Belajar}

Pada pembelajaran berbasis masalah tahap pembelajaran yang memberikan kontribusi yang besar dalam meningkatkan kemandirian belajar siswa 
adalah tahap orientasi siswa pada masalah dan tahap membimbing penyelidikan individual maupun kelompok. Pada tahap orientasi siswa pada masalah siswa dapat mengkontruksikan sendiri pengetahuan yang dimilikinya karena siswa dituntut untuk belajar mandiri dengan menemukan sendiri konsep pengethauan dari permasalahan yang diberikan oleh guru. Jadi, guru tidak memberitahukan konsep pengetahuan secara langsung kepada siswa.

Selanjutnya pada tahap membimbing penyelidikan kelompok dimana peran guru mengawasi jalannya diskusi kelompok di kelas dan juga membimbing siswa dalam mengumpulkan informasi dari berbagai sumber sehingga mengajarkan siswa untuk menjadi penyelidik yang aktif dan dapat menggunakan strategi yang tepat dalam menyelesaikan masalah yang akan diselidikinya. Guru hanya memberikan bantuan pada saat siswa benar-benar membutuhkan. Jadi, siswa dapat belajar untuk mencari dan menyelesaikan permasalahan tersebut secara mandiri sehingga akhirnya kemandirian belajar siswa terbentuk.

Dari hasil penelitian diperoleh bahwa seluruh indikator kemandirian belajar mengalami peningkatan baik di kelas eksperimen maupun kelas kontrol dimana peningkatan kemandirian belajar siswa di kelas eksperimen yang diberi pembelajaran berbasis masalah lebih tinggi daripada siswa di kelas kontrol yang diberi pembelajaran langsung. Walaupun rata-rata $\mathrm{N}$-gain kemandirian belajar siswa di kelas eksperimen yang diberi pembelajaran berbasis masalah masih berada dalam kategori sedang yaitu sebesar 0,5669 dan pada siswa yang di kelas kontrol masih berada dalam kategori rendah yaitu sebesar 0,1805 . Peningkatan kemandirian belajar siswa di kelas eksperimen yang diberi pembelajaran berbasis masalah yang diperoleh dalam penelitian ini lebih baik jika dibandingkan dengan hasil penelitian Suheri (2013) yang mana diperoleh peningkatan kemandirian belajar siswa di kelas eksperimen yang diberi pembelajaran berbasis masalah sebesar 0,33. Namun, peningkatan kemandirian belajar siswa di kelas kontrol yaitu sebesar 0,185 dalam penelitian Suheri lebih baik dari pada peningkatan kemandirian belajar siswa di kelas kontrol pada penelitian ini.

\section{Interaksi Antara Pembelajaran dan} Kemampuan Awal Matematika Siswa Terhadap Peningkatan Kemampuan Berpikir Kritis Matematis dan Kemandirian Belajar Siswa

Pada awalnya berdasarkan teoriteori yang mendukung serta penelitian yang relevan peneliti menduga ada 
interaksi antara kemampuan awal matematika siswa, pembelajaran dan peningkatan kemampuan berpikir kritis matematis dan kemandirian siswa. Namun, hasil penelitian ini menunjukkan bahwa secara signifikan tidak terdapat interaksi antara faktor pembelajaran dan faktor kemampuan awal matematika siswa dalam mempengaruhi peningkatan kemampuan berpikir kritis matematis siswa dan kemandirian belajar siswa.

Ada beberapa faktor yang menyebabkan hal tersebut terjadi salah satunya adalah faktor kegiatan pembelajaran yang dilaksanakan khususnya di kelas eksperimen yang diberi pembelajaran berbasis masalah. Berdasarkan hasil observasi kegiatan pembelajaran yang dilakukan oleh observer diperoleh bahwa rata-rata kemampuan guru dalam mengelola pembelajaran pada pertemuan pertama rata-ratanya sebesar 60 (75\%), pertemuan dua rata-ratanya sebesar $61 \quad(76,2 \%)$, pertemuan ketiga $62(77,5 \%)$, pertemuan keempat dan kelima sebesar 64 (78,7\%). Sedangkan rata-rata kemampuan guru dalam mengelola pembelajaran secara keseluruhan adalah sebesar 61,8 (77,2\%). Nilai rata-rata hasil observasi kegiatan pembelajaran pada setiap pertemuan tersebut berada dalam kategori baik dan antara suatu pertemuan dengan pertemuan berikutnya selalu menunjukkan adanya peningkatan ke arah yang lebih baik. Selain itu, nilai masing-masing indikator pada lembar hasil observasi kegiatan pembelajaran rata-rata menunjukkan angka 3 (kategori baik) dan angka 4 (kategori sangat baik). Hasil observasi kegiatan pembelajaran tersebut menunjukkan pembelajaran memberikan pengaruh yang cukup besar atau dominan terhadap peningkatan kemampuan berpikir kritis matematis dan kemandirian belajar siswa. Pengaruh pembelajaran tersebut bahkan diduga lebih besar daripada pengaruh kemampuan awal matematika. Hal ini lah yang menyebabkan tidak ada interaksi antara kemampuan awal dan pembelajaran terhadap peningkatan kemampuan berpikir kritis matematis dan kemandirian belajar siswa.

Selanjutnya, dari hasil analisis data ditemukan bahwa besar bahwa selisih rata-rata peningkatan kemampuan berpikir kritis matematis antara siswa yang diberikan pembelajaran berbasis masalah dan pembelajaran langsung untuk kategori KAM rendah, sedang dan tinggi tidak menunjukkan perbedaan secara signifikan. Hal yang sama juga berlaku pada selisih rata-rata peningkatan kemandirian belajar siswa. Jadi, pada penelitian ini adanya pembelajaran yang berbeda tidak menunjukkan adanya perbedaan rata-rata peningkatan kemampuan berpikir kritis 
matematis dan kemandirian belajar siswa yang lebih besar pada salah satu kategori KAM baik kategori rendah, sedang maupun tinggi.

Dari beberapa temuan di atas, peneliti dapat mengambil kesimpulan bahwa tidak terdapat interaksi antara pembelajaran dengan kemampuan awal matematika siswa terhadap peningkatan kemandirian belajar siswa. Hasil penelitian ini sejalan dengan hasil penelitian Syahbana (2012) yaitu tidak terdapat interaksi antara pendekatan pembelajaran dan pengetahuan awal matematik siswa (tinggi, sedang, rendah) terhadap peningkatan kemampuan berpikir kritis matematis siswa dan juga hasil penelitian Fauzi (2011) yaitu tidak terdapat interaksi antara pendekatan pembelajaran (PMR, PBM) dengan pengetahuan awal matematik siswa baik kategori atas, tengah dan bawah dalam peningkatan kemandirian belajar siswa.

\section{Kesimpulan}

Berdasarkan hasil penelitian dan pembahasan, diperoleh beberapa simpulan sebagai berikut: (1) Peningkatan kemampuan berpikir kritis matematis siswa yang diberi pembelajaran berbasis masalah lebih tinggi daripada yang diberi pembelajaran langsung; (2) Tidak terdapat interaksi antara pembelajaran dengan kemampuan awal matematika siswa terhadap peningkatan kemampuan berpikir kritis matematis siswa; (3) Peningkatan kemandirian belajar siswa yang diberi pembelajaran berbasis masalah lebih baik daripada yang diberi pembelajaran langsung; (4) Tidak terdapat interaksi antara pembelajaran dengan kemampuan awal matematika siswa terhadap peningkatan kemandirian belajar siswa.

\section{Saran}

Berdasarkan hasil penelitian, pembahasan, dan simpulan, saran-saran yang dapat diberikan diantaranya adalah sebagai berikut:

1. Bagi Guru Matematika

Pembelajaran berbasis masalah sebaiknya diterapkan oleh guru matematika untuk dapat meningkatkan kemampuan berpikir kritis matematis dan kemandirian belajar siswa. Bagi guru yang akan mencoba pembelajaran berbasis masalah hendaknya memperhatikan hal-hal berikut yaitu pada saat siswa menyelesaikan masalah, guru jangan terlalu cepat memberikan bantuan kepada siswa sampai siswa benarbenar membutuhkannya dan hendaknya bantuan yang diberikan guru berupa bantuan tidak langsung dengan pengajuan petunjuk-petunjuk yang menghubungkan pengetahuan 
awal matematika siswa dengan masalah yang dihadapi sehingga siswa menemukan sendiri penyelesaian masalah yang diberikan oleh guru.

2. Bagi Peneliti Selanjutnya

Peneliti lanjut yang hendak melakukan penelitian sejenis hendaknya mengkaji aspek-aspek kemampuan berpikir tingkat tinggi dan aspek afektif yang lain serta melakukan penelitian pada tingkat sekolah dan materi yang belum terjangkau oleh peneliti saat ini dan hendaknya peneliti lanjut dapat merancang bahan ajar dan instrumen penelitian yang jauh lebih baik lagi.

3. Bagi Lembaga Terkait

Untuk lembaga terkait hendaknya mensosialisasikan dan memberikan pembekalan wawasan kepada guru matematika tentang pembelajaran berbasis masalah untuk diterapkan di kelas agar dapat meningkatkan kemampuan matematika dan afektif siswa serta menyediakan fasilitasfasilitas yang dibutuhkan agar pembelajaran yang inovatif bisa dilaksanakan di kelas.

\section{Pustaka}

Arends. 2007 . Belajar untuk Mengajar Edisi Ketujuh/Buku

Dua. Terjemahan oleh Helly
Prajitno Soetjipto dan Sri Mulyantini Soetjipto. 2008.Yogyakarta : Pustaka Pelajar.

Cahyo, A. N. 2013. Panduan Aplikasi Teori- Teori Belajar Mengajar Teraktual dan Terpopuler. Yogyakarta: Diva Press.

Depdiknas. 2006. Standar Isi Mata Pelajaran Matematika Tingkat Sekolah Dasar dan Menengah. Jakarta: Depdiknas.

Fahrurazy. 2011. Penerapan Pembelajaran Berbasis Masalah untuk Meningkatkan Kemampuan Berpikir Kritis dan Komunikasi Siswa Sekolah Dasar. Jurnal UPI, (Online), Edisi Khusus No.1, (http://jurnal.upi.edu/file/8 $\underline{\text { Fachruraz }}$ i.pdf, diakses 25 Maret 2013).

Fauzi, A. 2011. Peningkatan Kemampuan Koneksi Matematis Dan

Kemandirian Belajar Siswa Dengan Pendekatan Pembelajaran Metakognitif Di Sekolah Menengah Pertama. Makalah disajikan dalam Seminar Internasional dan Konferensi Nasional ke-4, Jurusan Pendidikan Matematika UNY, Yogyakarta, 21-23 Juli.

Hargis, J. 2000. The Self-Regulated Learner Advantage: Learning Science on the Internet. Electronic Journal of Sciene Education, $\begin{array}{lll}\text { (Online), } & \text { Vol.4 }\end{array}$ Peningkatan ... (Tanti Jumaisyaroh) 
(http://wolfweb.unr.edu/homepage/c rowther/ejse/hargis.html, diakses 25 November 2013)

Ismaimuza,

D. 2010. Pengaruh Pembelajaran Berbasis Masalah dengan Strategi Konflik Kognitif terhadap Kemampuan Berpikir Kritis Matematis dan Sikap Siswa SMP. Jurnal Pendidikan Matematika UNSRI, (Online), Vol. 4 No.1, (http://eprints.unsri.ac.id/830/ 1/0_Dasa_Ismaimuza_1-10.pdf. diakses 4 April 2013).

Lilik, S., Djannah,W., dan Wagimin. 2013. Tingkat Penguasaan SelfRegulated Learning Skills Ditinjau Dari Segi Prestasi Belajar dan Lama Studi Pada Mahasiswa FKIP UNS. Jurnal Conselium, Vol.1 No.1, (online), (http://jurnal.fkip.uns.ac.id/ index.php/counsilium/issue/view/84. diakses 6 September 2013).

Napitupulu, E.E. 2008. Developing Reasoning Skills and Problem Solving Through Problem Based Learning. Jurnal Pendidikan Matematika Paradikma UNIMED.

Noer, S.H. 2009. Peningkatan Kemampuan Berpikir Kritis Matematis Siswa SMP Melalui Pembelajaran Berbasis Masalah. Makalah disajikan dalam Seminar Nasional Matematika dan Pendidikan Matematika Jurusan
Pendidikan Matematika FMIPA UNY, Yogyakarta, 5 Desember.

Riyanto, Y. 2010. Paradigma Baru Pembelajaran. Jakarta : Kencana Prenada Media Group.

Santoso, F.G.I. 2013. Pengaruh Pembelajaran Berbasis Masalah Terhadap Motivasi Berprestasi Belajar Matematika Siswa. Jurnal FMIPA, (Online), Vol.1 No.2, (ikippgrimadiun.ac.id/ejournal /id/node/873, diakses 4 April 2014). Somakim. 2011. Peningkatan Kemampuan Berpikir Kritis Matematis Siswa Sekolah Menengah dengan Penggunaan Pendidikan Matematika Realistik. Jurnal Forum MIPA, (Online), Vol. 14, No. 1. (http://eprints.unsri.ac.id/1526/1/08 = Somakim_Matematika-\%284248\%29.pdf. diakses 12 Desember 2013).

Sugandi, A. 2013. Pengaruh Pembelajaran Berbasis Masalah Dengan Setting Kooperatif Jigsaw Terhadap Kemandirian Belajar Siswa SMA. Jurnal Ilmiah Program Studi Matematika STKIP Siliwangi Bandung, (Online), Vol. 2 No.2,(ejournal.stkipsiliwangi.ac.id/index.ph $\mathrm{p} /$ infinity/article /view /31/30, diakses 21 Januari 2014).

Suhery, D. 2013. Peningkatan Kemampuan Pemecahan Masalah 
Matematika dan Kemandirian Belajar Siswa SMA di Kabupaten Aceh Tenggara Melalui Pembelajaran Berbasis Masalah. Medan: Tesis PPs UNIMED. Tidak diterbitkan.

Sumarmo, U. 2004. Kemandirian Belajar Apa, Mengapa dan Bagaimana Dikembangkan pada Peserta Didik. Makalah disajikan pada Seminar Pendidikan Matematika di Jurusan Pendidikan Matematika FMIPA Universitas Negeri Yogyakarta, tanggal 8 Juli.

Susanto, A. 2013. Teori Belajar dan Pembelajaran di Sekolah Dasar. Jakarta: Prenada Media Group.

Sutama. 2011. Pengelolaan Pembelajaran Matematika untuk Penanaman dan Pengembangan Karakter Anti Korupsi. Makalah disajikan dalam Seminar Nasional Matematika dan Pendidikan Matematika Jurusan Pendidikan Matematika Universitas
Muhamadiyah Surakarta, Surakarta, 24 Juli.

Syahbana, A. 2012. Peningkatan Kemampuan Berpikir Kritis Matematis Siswa SMP Melalui Pendekatan Contextual Teaching and Learning. Jurnal Edumatica,(Online),Vol. 2, No.1, (http://online-journal.unja.ac.id/ index.php/edumatica/article/view/60 . diakses 23 Mei 2013).

Usdiyana, D., Purniati, T., Yulianti, K., dan Harningsih, E. 2009. Meningkatkan Kemampuan Berpikir Logis Siswa SMP Melalui Pembelajaran Matematika Realistik. Jurnal Pengajaran MIPA, (Online), Vol. 13, No.1, (http://tugasblog pertama.googlecode.com/files/Jurna 1\%20MIPA1\%20Dian\%20Baru.pdf. diakses $14 \quad$ November 2013).

Yamin, M. 2008. Paradigma Pendidikan Kontruktivistik. Jakarta: Gaung Persada Press. 
